\title{
Health Implication of Physicochemical Properties of Sump Oil Polluted and Remediated Soil
}

Nwodu J. $\mathrm{A}^{1,2 *}$, Nwachukwu N,, Ibegbulem C. $\mathrm{O}^{2}$, Iwueke A. V', Akumefula M. I ${ }^{1}$, Chukwuemeka U. V1, Ohueri E. $\mathrm{O}^{1}$

${ }^{1}$ Department of Science Laboratory Technology, Imo State Polytechnic, Umuagwo, Nigeria

${ }^{2}$ Department of Biochemistry, Federal University of Technology, Owerri, Nigeria

*Corresponding Author : Nwodu J.A, Department of Chemistry/Biochemistry, Imo State Polytechnic Umuagwo Ohaji, Imo State Nigeria

Article Info

Volume 8, Issue 3

Page Number : 854-862

\section{Publication Issue}

May-June-2021

\section{Article History}

Accepted : 15 June 2021

Published : 22 June 2021

\section{ABSTRACT}

Physicochemical properties of sump oil polluted and remediated soil were studied. Five $(5 \mathrm{~kg})$ of soil was polluted with different concentrations $(00,50$, 150 and $300 \mathrm{ml}$ ) of sump oil. The physiochemical properties of these soils were analyzed before pollution and after pollution using standard analytical procedures. The result of physicochemical parameters of the unpolluted, polluted and treated soils show significant $(\mathrm{P} \leq 0.05)$ increase which are as follows: organic carbon\%: (0.97,1.69-2.15, 0.8-1.49) organic matter\%: (1.68, 2.92-3.71, 1.3-2.57 )Total exchangeable acidity (0.5, 1.2-1.4, 0.5-1.1) Total nitrogen content $\mathrm{mol} / \mathrm{kg}:(0.08,0.14-0.18,0.06-0.12)$, Cataion exchange capacity(3.14, 4.18-5.17, 3.78-5.76) Calcium content mol/kg:(1.2, 1.6-2.6, 1.42.6),Potassium mol/kg:( 0.18,0.18-0.22, 0.17-0.26) show significant $(\mathrm{P} \leq 0.05)$ decrease for $\mathrm{PH}:(5.65,4.11-4.31,5.67-7.2)$ and magnesium $\mathrm{mol} / \mathrm{kg}:(5.25,1.86-$ 2.66, 4.26-7.63) The study concluded that sump oil pollution significantly changes the physicochemical properties of the soil and hence impacts it negatively. Treatment with house hold waste remediated the polluted soil and reversed most of the negative impact of the pollution.

Keywords : Remediation, Pollution, Sump- Oil, House-Hold, Waste

\section{INTRODUCTION}

Oil pollution in Nigeria is a major source of concern to people especially those living in the crude oil richareas (Ohanmu et al., 2017). Pollution from sump oil is one of the biggest environmental problems in Nigeria. Engine oil is a petroleum product used to minimize the friction between engine surfaces. It is production is by vacuum distillation of crude oil (Kalichesvky and Peters, 2010).It contains chemical additives like amines, phenols, benzene, calcium, zinc, barium, magnesium, phosphorus, sulphur, and lead (Obidike, 2015).Sump oil is a product from automobile mechanic shops or electrical engine 
repairer workshops after servicing the vehicles engines, generating set and other types of machines. It is usually recognized by its dark brown to black colour. It is harmful to the soil environment. It chiefly made up of mixture of different chemicals including low to high molecular weight carbon compounds, lubricants additives, decomposition products and heavy metals which are poisonous to the soil and human health (Adedokun and Ataga, 2014).

Nigerians consumes more than 87 million liters of lubricant annually and adequate attention has not been given to its proper disposal (Obidike, 2015).Disposal of the lubricant into gutters, water drains, open vacant plots and farms is a common practice in Nigeria. This mode of indiscriminate disposal of the sump oil increases pollution incidents in our environment and it has been proved to be more widespread than crude oil pollution (Atuanya, 2014). This leads to the pollution of streams and rivers as well as underground water and agricultural land thereby depleting the mineral resources used by plants for proper growth and development (Desong, 2010).Various specific changes in soil properties occur in the physical, chemical and microbiological content of soils contaminated with lubricant oil. Oil may displace air and water thereby leading to anaerobic conditions in soil. The presence of lubricant oil in soil increase bulk density, decrease water holding capacity and aeration propensity (Obidike, 2015). There are also reports of reduced nitrogen, phosphorus, potassium, magnesium, calcium, sodium and increased levels of heavy metals in soils contaminated with oil.

\subsection{EFFECTS OF SUMP OIL ON SOIL}

Sump oil contaminated soils has been reported to affect the soil properties. The effects of sump oil on soil indicated that the $\mathrm{pH}$ status, carbon content, total nitrogen, available phosphorus, cation exchange capacity, among others were impacted negatively depending on the level of pollution exposure, Atlas, R.M. (2005). Study of Amadi et al. (2013) reported that most soil properties were adversely affected in oil-contaminated lands. It has been observed that the effect of sump oil and other pollutants on soil chemical properties was determined by the following: Soil $\mathrm{pH}$, temperature, supply of oxygen, the structure of the contaminant molecules, their toxicity and that of their intermediate decomposition products. Petroleum products adversely affect biological systems and particularly, the soil health status (Henery and Hershey, 2002).One of the biggest concerns associated with crude oil pollution in the environment is the risk to farmland, and potable drinking water contamination (Ohanmu et al., 2017). The effect of oil pollution range from disruption of plant water relations, direct impact to plant metabolism, for instance, nutrient uptake, toxicity to living cells for example the liquid component of the protoplasm, reduced oxygen exchange between the atmosphere and the soil affecting root function to reduction in biomass (Ohanmuet al., 2018). The soil health is the continued capacity of the soil to function as a vital living system, within ecosystem and landuse boundaries, to sustain biological productivity, promote the quality of air and water environments and maintain plant, animal and human health. Several bio-indicators of soil health and quality have been developed and reviewed (Henery and Hershey, 2002).

\subsection{BIOREMEDIATION}

This is a natural way of treating, managing, or removing environmental contaminants from its environment. Bioremediation of soils is fast becoming an important alternative to chemical treatment. Wang et al., (2000) Remediation of sump oil polluted soil can be done using Ash generally called surfactants. Surfactant (Ash) improves the availability of contaminants for degradation by microorganisms. They act by partitioning preferentially at interphase and exhibiting high surface and emulsifying activities (De Song, 2010). The addition of organic matter to sump oil contaminated soil have also been reported to be beneficial, as it is a source of co-substrates, 
nutrients and microorganisms, and ameliorates the chemistry and water-retaining capacity of the soil (Adekunle et al., 2012). The use of fresh organic materials for amendment such as Vegetables to incubate with the contaminated soil produces a thermophilic phase and the process is called composting (Fagbemi et al., 2005).

Leaves of plant have shown usefulness in remediation of crude oil contaminated soils by Increase in organic carbon and organic matter of crude oil contaminated soil. Remediation of oil polluted soil using peels may impact bio stimulation efficiency on the soils and so lead to reduction in hydrocarbons and increasing the bacteria load of the soil. This may be due to the biodegradation by nutrient additions or other processes such as volatilization (Nunes et al, 2020).Peels which are often disposed indiscriminately is a carbon source in bioremediation of polluted soil. It can be used as adsorbent and as a filter medium for mine water. (Ayansian et al., 2014).Cassava peel is an agro-industrial waste that is discarded in Nigeria, yet it is good organic manure. It may be used in the treatment of contaminated soil. The peel enhances aeration and increases the water-retaining capacity of the soil, thus promoting bioremediation (Henery and Hershey, 2002).

\section{MATERIALS AND METHODS}

\subsection{Collection of samples}

Sump oil (S0) was collected from different Mechanic workshop close to the Army Barracks (distance 465.01m) Obinze in Owerri West Local Government Area, Imo State. The sump oils were pooled together.

The unpolluted soil was collected $(0-6 \mathrm{~cm})$ from the forest reserve (Latitude: $5.417 \mathrm{o}$ and Longitude; 7.0094o) in Imo State Polytechnic Umuagwo, in Ohaji Local Government Area of Imo State. The wood ash was collected from Imo State Polytechnic and environs (Laltitude:5.3342o and Longitude;6.9545o). Peels and vegetables were collected from Eke
Umuagwo Market,(Latitude 5.3062 o and longitude 6.9436 o).

\subsection{Pollution of soil samples}

The soil was sieved using a $2.0 \mathrm{~mm}$ sieve in which contaminants were removed and properly mixed. Then, $5.0 \mathrm{~kg}$ of this soil sample was weighed and put into 12.0 different $(25.0$ by $40.0 \mathrm{~cm}$ ) polythene bags and grouped into 4 with 3 replicates. Each replicate was polluted with different volumes of sump oil ( $0 \mathrm{ml}$, $50 \mathrm{ml}, 150 \mathrm{ml}$ and $300 \mathrm{ml}$ ) as shown in the Table 1.0 below and allowed undisturbed for 48 hours. Aliquot of $50.0 \mathrm{~g}$ each of the unpolluted and polluted soil samples were taken to the soil laboratory of the department of Soil Science, Federal University of Technology Owerri, for analyses.

Table 1.0 Experimental Design, treatment of replicates with domestic waste

\begin{tabular}{lll}
\hline SAMPLE & CODE & REPLICATE \\
\hline $5 \mathrm{~kg}$ of Soil $+00 \mathrm{ml}$ & A(control) & 3
\end{tabular}

sump oil

$5 \mathrm{~kg}$ of Soil $+50 \mathrm{ml} \quad$ B 3

\section{Sump oil}

$5 \mathrm{~kg}$ of Soil $+150 \mathrm{ml} \quad$ C 3

Sump oil

$5 \mathrm{~kg}$ of Soil $+300 \mathrm{ml} \quad$ D

3

\section{Sump oil}

\section{3: TREATMENT WITH HOUSE-HOLD WASTE (ASH, PEELS AND VEGETABLE WASTE)}

After 72 hours, the polluted soil sample replicates where treated separately with the waste; $1.0 \mathrm{~kg}$ of wood ash, 1.kg of vegetables (50\% pumpkin and 50\% 
water leaf), $1.0 \mathrm{~kg}$ of peels( $50 \%$ cassava and $50 \%$ yam) respectively as shown in table 4 , thoroughly mixed, and allowed for two weeks for the waste to properly decay. The treated soil replicates were properly mixed and $50.0 \mathrm{~g}$ each were sampled and taken for laboratory analyses.

\section{4: Laboratory analysis}

Physicochemical analysis were done using standard analytical procedure described by Nwakaudu et;al 2012 and Blake, 1986. The soil samples were delivered to the laboratory in polythene bags for analysis. The soil samples were made into three replicates for the analysis.

\subsubsection{Soil Analysis Procedure}

Soil $\mathrm{pH}$

Soil $\mathrm{pH}$ was measured using the Labtech $\mathrm{pH}$ meter. The meter was standardized first with buffer 9.2 and buffer 4.0 respectively. Air-dried soil (20.0g) was passed into a $50.0 \mathrm{ml}$ beaker and $20.0 \mathrm{ml}$ of distilled water was added to it. The suspension was stirred several times with a glass rod for 30.0 minutes. The electrode of the $\mathrm{pH}$ meter was inserted into the suspension and the $\mathrm{pH}$ was measured in a soil-water ratio.

\section{ORGANIC CARBON DETERMINATION}

Walkley-Black method was used. Soil (1.0g) was weighed and placed in the $250.0 \mathrm{ml}$ flask and $10.0 \mathrm{ml}$ of $1.0 \mathrm{~N} \mathrm{K2CrO7}$ solution was pipetted accurately into each flask and swirled gently to disperse the soil. Concentrated $\mathrm{H} 2 \mathrm{SO} 4(20 \mathrm{ml})$ was added rapidly from a measuring cylinder and immediately swirled and allowed to stand on a sheet of asbestos for about 30.0 minutes, $100.0 \mathrm{ml}$ of Distilled water was added and allowed to cool down. $5.0 \mathrm{ml}$ of O-phosphoric acid was added to sharpen the colour change of the end point. An indicator (4 drops) was added and titrated with $0.5 \mathrm{~N}$ Ferroussulphate solution on a white background.

\section{SOIL ORGANIC MATTER (SOM)}

Measurement of SOM was carried out with approximately $10.0 \mathrm{~g}$ of air-dry soil. The Soil was placed in a $30.0 \mathrm{~mL}$ porcelain crucible $(5.0 \mathrm{~cm}$ diameter, $2.5 \mathrm{~cm}$ height), this was dried in a convection oven at $105.0^{\circ} \mathrm{C}$, and placed in a sealed desiccator to cool. These processes were repeated until the soil and crucible acquired a constant weight. Later a muffle furnace was preheated to $360.0^{\circ} \mathrm{C}$ and soil was heated in the furnace at that temperature for $2.0 \mathrm{~h}$. After $2.0 \mathrm{~h}$, the crucible with soil was removed from the furnace and placed in a desiccator to cool before being weighed. The difference in the weight of the crucible and soil pre-heating and post-heating was assumed to be the weight of SOM in the sample. A select number of samples were analyzed for SOM content multiple times to check repeatability of the results, and the measured SOM content of the samples was consistent for repeated number of analyses within $0.4 \mathrm{~g} \mathrm{SOM} \mathrm{kg-1,} \mathrm{which} \mathrm{is} \mathrm{less} \mathrm{than} \mathrm{a}$ $3.0 \%$ difference in measured SOM.

\section{TOTAL EXCHANGE ACIDITY DETERMINATION}

The method used was $\mathrm{KCl}$ extraction method. Air dried soil $(5.0 \mathrm{~g})$ was weighed into $50.0 \mathrm{ml}$ centrifuge tube and $30.0 \mathrm{ml}$ of $\mathrm{M}-\mathrm{KCl}$ was added and shaken. The content was centrifuged for $15.0 \mathrm{~min}$ and clear supernatant was decanted into $100.0 \mathrm{ml}$ volumetric flask. Another $30 \mathrm{ml}$ of M-KCL was added to the same soil sample and shaken for $30.0 \mathrm{mins}$. $\mathrm{KCl}$ extract (5.0ml) was pipetted into a $250.0 \mathrm{ml}$ Erlenmeyer flask and $100.0 \mathrm{ml}$ of distilled water was added. 5.0 drops of phenolphthalein indicator was added and titrated with $0.01 \mathrm{M} \mathrm{NaOH}$.

\section{TOTAL NITROGEN DETERMINATION}

The method used was Regular macro Kjeldhal method. Soil sample (2.0g) was weighed into Kjeldhal flask and $20.0 \mathrm{ml}$ of distilled water was added. The flask was swirled for few minutes and allowed to stand for 30.0 minute before $2.0 \mathrm{~g}$ of catalyst and $20.0 \mathrm{ml}$ of Conc $\mathrm{H} 2 \mathrm{SO} 4$ were added and heated continuously on a low 
heat. The flask was allowed to cool and slowly with shaking, $5.0 \mathrm{ml}$ of distilled water was added and the digest was transferred into another clean flask. $10.0 \mathrm{ml}$ of $\mathrm{H} 3 \mathrm{HO} 3$ solution was added into a $50.0 \mathrm{ml}$ Erlynmeyer flask, which is then placed under the condenser of the distillation apparatus. $\mathrm{NaOH}(10.0 \mathrm{ml}$ of $40.0 \%$ ) was added slowly into $10.0 \mathrm{ml}$ of digest in the flask which has been attached to the distillation apparatus. Temperature was raised until it boiled. Distillate $(50.0 \mathrm{ml})$ was collected and distillation was stopped. Ammonia liberated was titrated with standard $\mathrm{HCl}$ after 3 drops of indicator was added.

\section{CATION}

\section{EXCHANGE}

CAPACITY

\section{DETERMINATION}

Air dried soil (10.0g ) was weighed into $500.0 \mathrm{ml}$ Erlenmeyer flask and $40 \mathrm{ml}$ of neutral $1.0 \mathrm{~N} \mathrm{NH} 4 \mathrm{O}$ was added. The soil was leached with the neutral $1.0 \mathrm{~N}$ $\mathrm{NH} 4 \mathrm{O}$ reagent until no test for calcium can be obtained in the effluent solution (for calcium test add few drops $1.0 \mathrm{~N} \mathrm{NH4O,} 10.0 \%$ ammonium oxalate, and dilute $\mathrm{NH} 4 \mathrm{OH}$ to $10.0 \mathrm{ml}$ of the leachate in a test tube and heated to near the boiling point. The presence of $\mathrm{Ca}$ is indicated by a white precipitate or turbidity). The leachate was preserved for the determination of exchangeable cation (EC determination $\mathrm{k}, \mathrm{Ca}, \& \mathrm{Mg}$ ). The electrolyte was washed out with $170.0 \mathrm{ml}$ of $99.0 \%$ ethyl alcohol.

The soil was transferred and filtered to $500.0 \mathrm{ml}$ kjeldahl flask. Distilled water $(200.0 \mathrm{ml})$ and two drops of liquid paraffin were added. The solution $(60.0 \mathrm{ml})$ was distilled into $50.0 \mathrm{ml}$ of $2.0 \%$ boric acid solution and measured into $250.0 \mathrm{ml}$ of Erlenmeyer flask. 10.0 drops of bromocresol green-methyl red mixed indicator was added and the NH4-borate was titrated with standard $0.02 \mathrm{~N} \mathrm{H2SO} 4$. The blanks were run on the reagents and the titer was corrected with blank result.

\section{Ca, $\mathrm{Mg}$ and K DETERMINATION}

The leachates preserved from CEC determination were used for the determination of $\mathrm{Ca}$ and $\mathrm{Mg}$ with AAS and $\mathrm{K}$ with a flame photometer.

\section{RESULTS AND DISCUSSION}

The physico-chemical analysis carried out in this study before and after pollution with sump oil, showed that there was reduction in the $\mathrm{pH}$ of the contaminated soil compared to control soil samples. Although the $\mathrm{pH}$ of the control soil was not within the $\mathrm{pH}$ value between 6.5 and 7.5 considered optimum for the growth of many plants (Marschner, 2005), increase in acidity after the pollution was recorded. Soil $\mathrm{pH}$ is a major factor in the accessibility of elements in the soil for plant uptake (Marschner, 2005). Okon and Udofot (2012) reported that petroleum waste sludge adversely reduce microbial population by depleting essential inorganic nutrients and growth factors. Kayode et al (2009) noted reduced nitrogen, phosphorus, potassium, magnesium, calcium, and increased sodium in soils contaminated with oil. The total nitrogen content of the contaminated soil increased compared to the control. This increase in nitrogen content of the contaminated soil, contradicted the report that, in the presence of contamination in soil, the supply of carbon increases and the availability of nitrogen becomes limited (Atlas, 2005). Calcium, magnesium and potassium increased considerably in the presence of sump oil in the contaminated soil samples. Magnesium is very essential for the integrity of functional ribosomes (Chang and Hayes, 2014). There was increase in the available magnesium content in the sump oil contaminated soil samples compared to the control. An increase in the organic carbon and organic matter was also observed in the contaminated soils which definitely must have resulted from the application of the sump oil. Crude oil, from which sump oil was derived, contains principal elements such as oxygen, nitrogen, other than hydrogen and carbon (Obidike, 
2015). Spillage of used motor oils such as diesel pollutes the natural environment with hydrocarbon (Amadi et al., 2013).

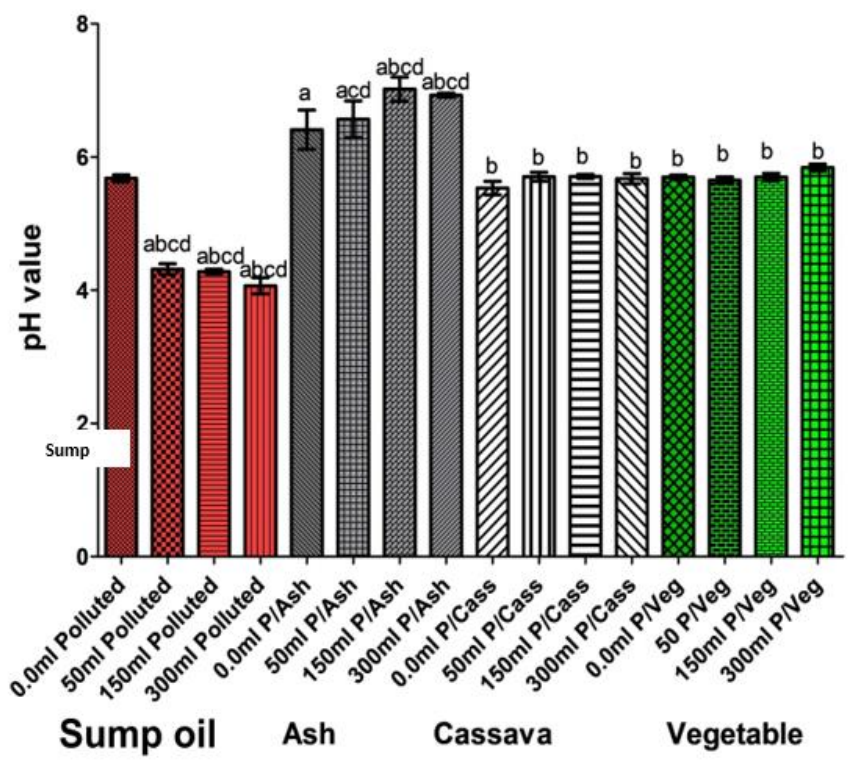

Figure 3.1 : Effect of the different concentration sump oil pollution on soil $\mathrm{pH}$ in different treatment with ash, cassava and vegetables.

The $\mathrm{PH}$ of the soil before pollution was 5.65 while sump oil pollution reduced to 4.11-4.31 after pollution. The treatment with household waste increased it again to 5.67- 7.20.

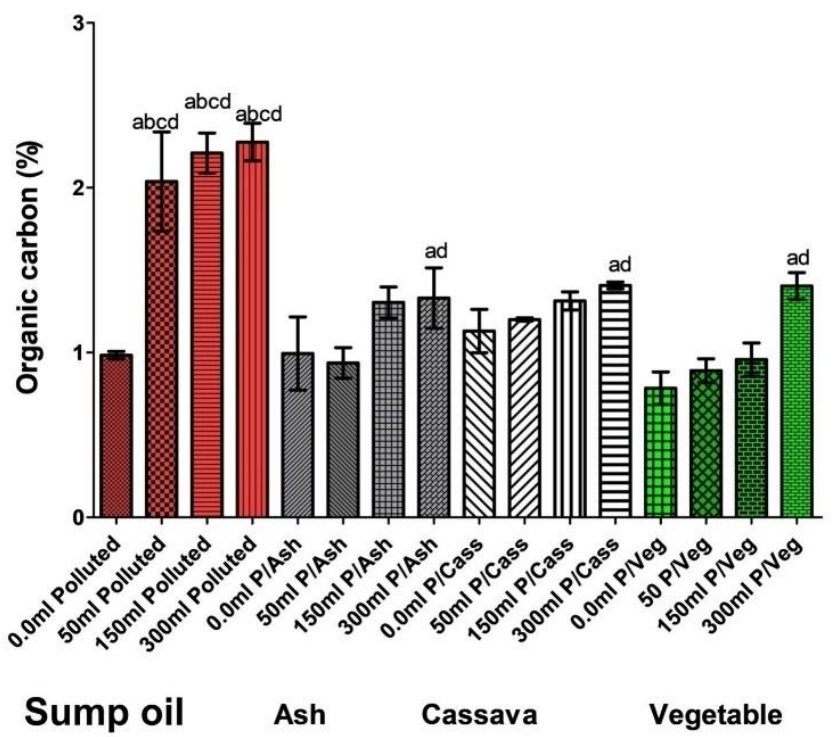

Figure 3. 2 : Effect of different concentrations of sump oil polluted soil on organic carbon content in different treatment with ash, cassava and vegetables.
The result above shows that Organic carbon content of soil was increased with increase in pollution with sump oil compared to control soil. The different treatments decreased concentrations down to within the control level.

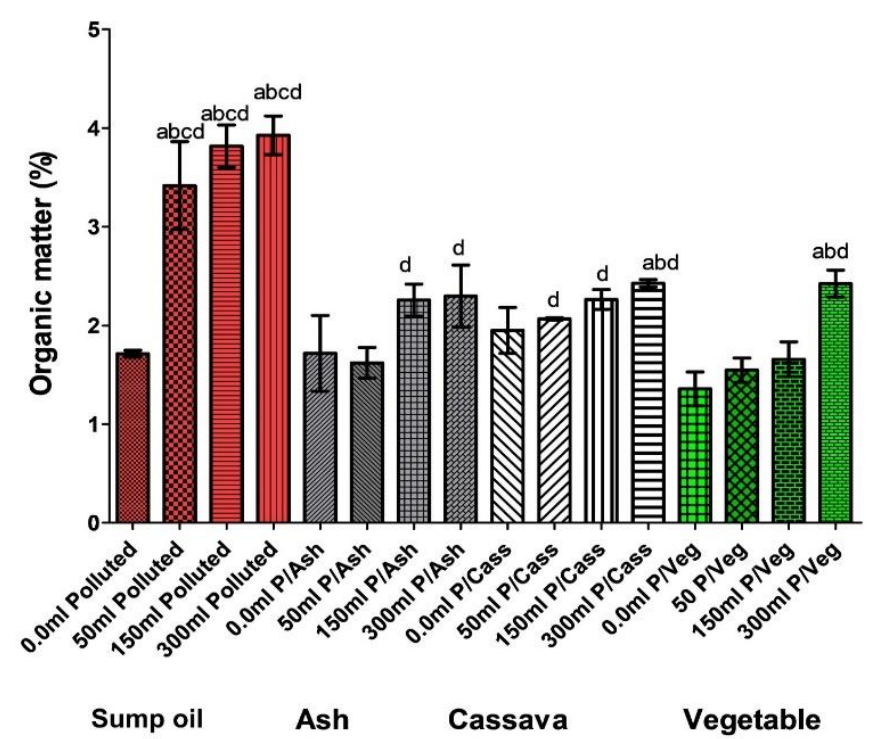

Figure 3.3 : Effect of sump oil pollution on organic matter content of different

Concentration SO in different treatment with ash, cassava and vegetables

Organic matter content of soil was increased with increase in pollution with sump oil compared to control soil. The different treatments decreased concentrations down to within the control level.

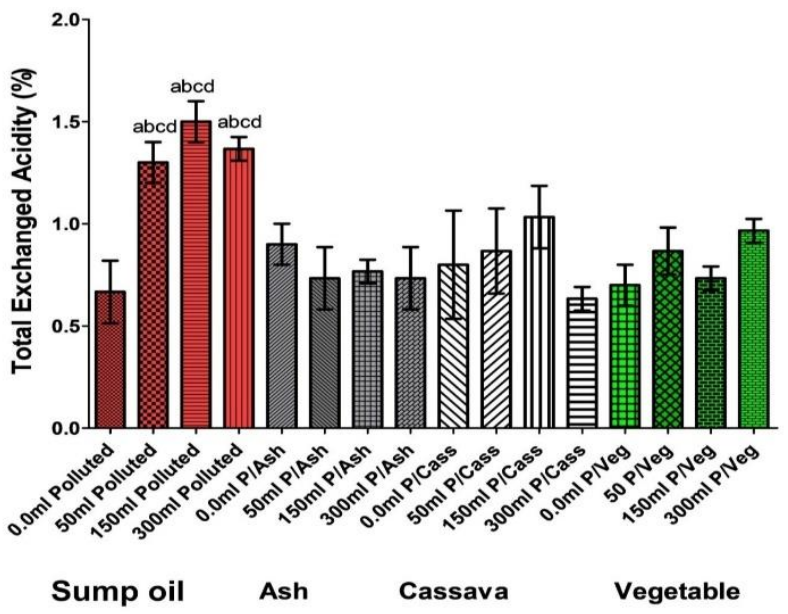

Figure 3.4 : Effect of sump oil pollution on total exchanged acidity content of sump oil polluted and treated soil samples. 
Total exchange acidity content of soil was increased with increase in pollution with sump oil compared to control soil. The different treatments decreased concentrations down to within the control level.

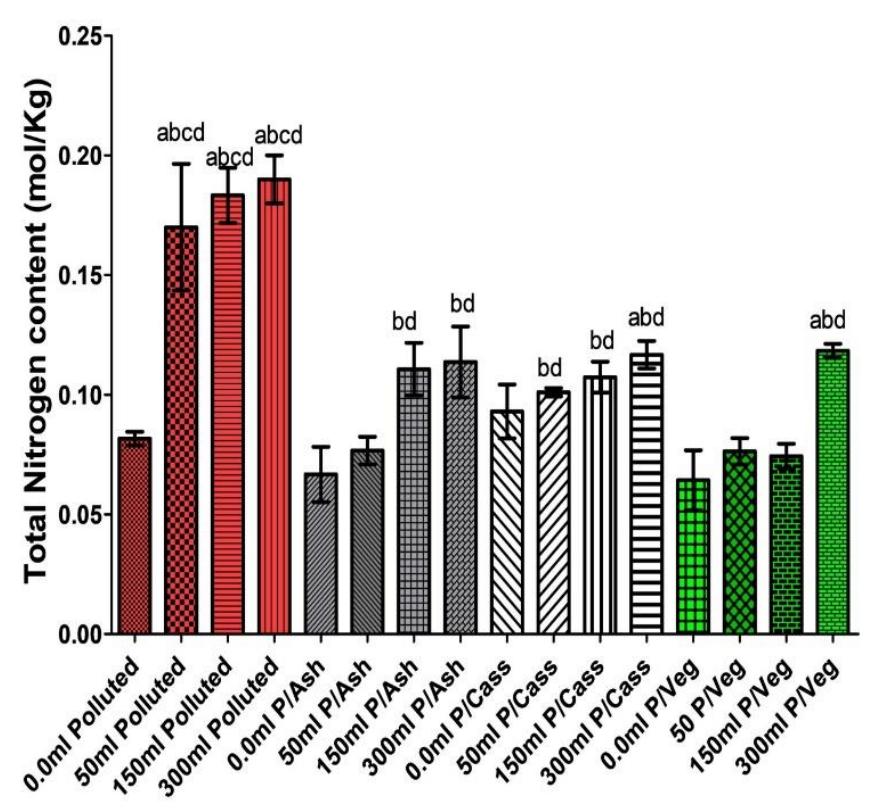

\section{Sump oil Ash Cassava Vegetable}

Figure 3.5 : Effect of sump oil pollution on total nitrogen content of soil samples

Total Nitrogen content of soil was increased with increase in pollution with sump oil compared to control soil. The different treatments decreased concentrations down to within the control level.

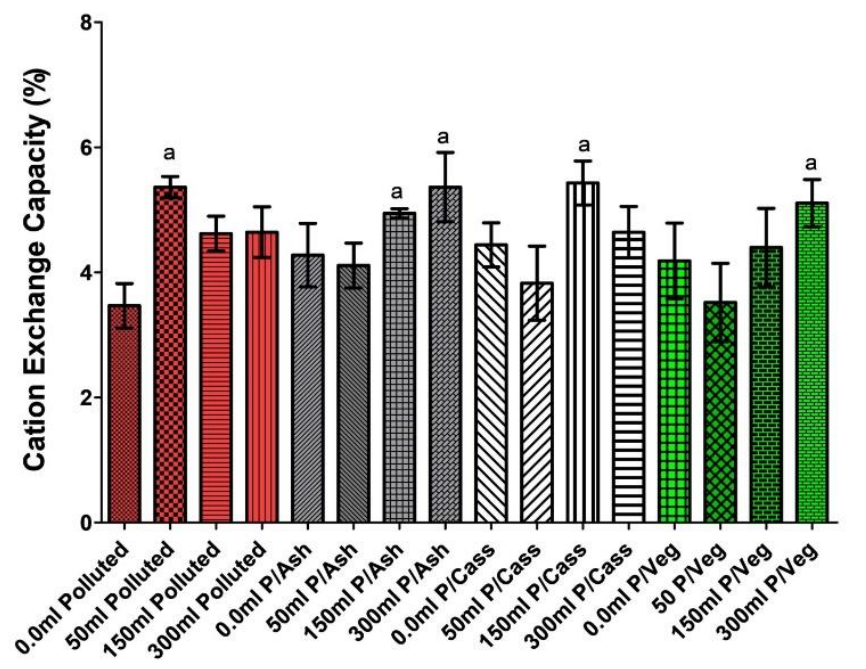

Sump oil
Cassava
Figure 3.6 : Effect of sump oil pollution on cation exchange capacity of sump oil polluted and treated soil samples.

Cation exchange capacity of soil was increased with increase in pollution with sump oil compared to control soil. The different treatments did not show significant reduction.

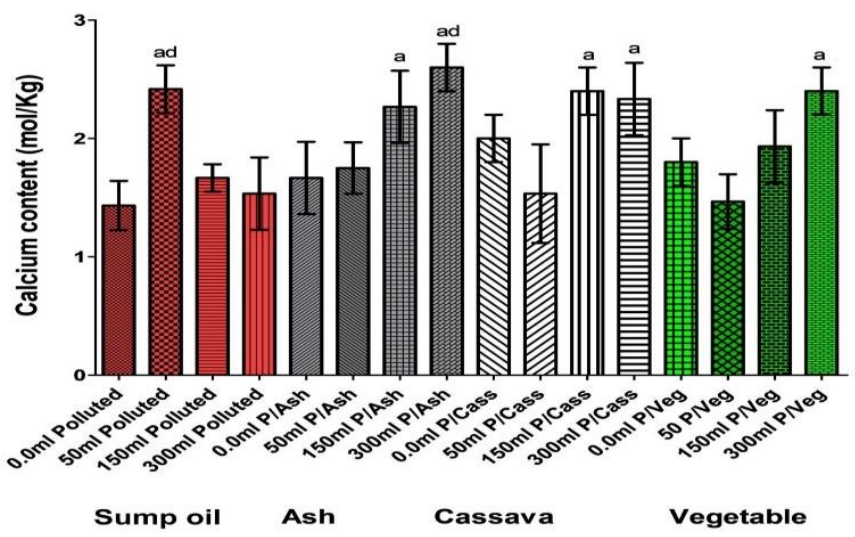

Figure 3.7 : Effect of sump oil pollution on calcium content of sump oil polluted and treated soil samples. There was no significant change on the calcium of unpolluted, polluted and treated soil samples.

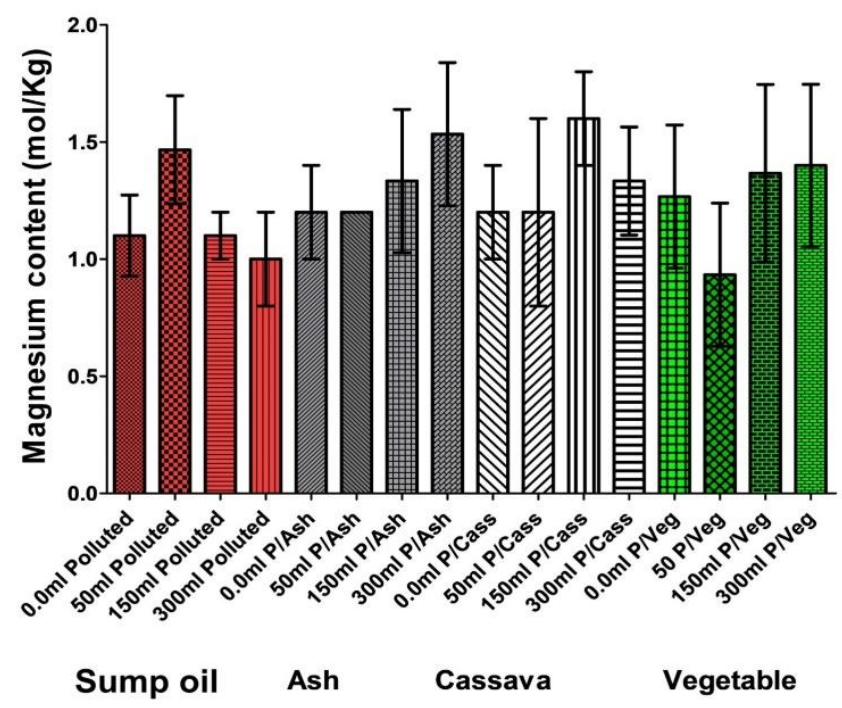

Figure 3.8 : Effect of sump oil pollution on magnesium content of soil samples.

There was no significant change or pattern on the magnesium of unpolluted, polluted and treated soil samples. 


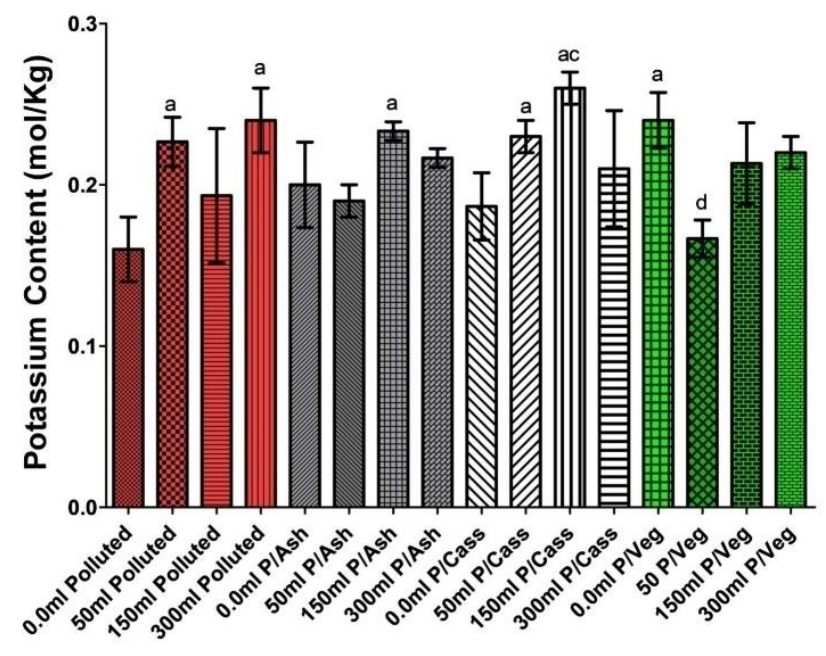

Sump oil Ash Cassava Vegetable

Figure 3.9 : Effect of sump oil pollution and treatments on potassium content of soil samples

The result shows that there was significant increase on the potassium content of soil polluted with sump oil compared with polluted but treated soil samples did not show significant reduction.

\section{CONCLUSION}

The physicochemical analysis carried out on this study before and after pollution with sump oil and subsequent treatment with household waste showed that there were significant effects of sump oil pollution on soil properties compared to control soil samples. The health implication of polluted environment through bioaccumulation of sump-oil is seen in the depletion of physicochemical properties and nutrients. The applied household wastes positively increased soil quality. The effect observed with the treatment was a function of oil dose and applied organic household waste type.

\section{ACKNOLEDGEMENT/ FUNDING}

This research was funded by the Tertiary Education Trust Fund Institutional Based Research (TETFUND IBR, grant No:

which was disbursed through Imo State Polytechnic, Umuagwo, Nigeria.

\section{REFERENCES}

[1]. Ayansian, A. D. V., Adebola, M. A. and Adeyemi, A. O. (2014). Some microorganisms associated with soils exposed to cassava (MannihotEsculatum) peels. Amer. J.Res. Comm. 2(9):155-162.

[2]. Adedokun, O.M. and A.E. Ataga, 2014. Effects of amendments and bioaugumentation of soil polluted crude oil, automotive gasoline oil, and spentengine oil on the growth of cowpea (Vignaunguiculata L. Walp). Sci. Res. Essay,2(5):147-149.

[3]. Adekunle, A.A., Adekunle, I. M. \&Tobit. (2012). Assessing the Effect of Bioremediation Agent Made from Local Resource Materials in Nigeria on Soil pH.J. Emerg. Trends Eng. Appl. Sci.3(3), 526-532.

[4]. Amadi, A., Samuel, D. A. and Anthony, M. (2013). The effect of crude oilspillage on the soil microbial properties of a tropical rainforest.Journal of Water, Air and Soil Pollution 67 (1-3): 28-30.

[5]. Atlas, R.M. (2005). Stimulated Petroleum Biodegradation. Critical Rev. Microbial.5:371386.

[6]. Atuanya, E.I. (2014). Effect of oil pollution on physical and chemical properties of soil. A case study of waste oil contaminated Delta soil in Bendel State. Nigeria J. Appl. Sci. 5: 155-76.

[7]. Blake, G.R. and Hartge, K.H. (1986).Bulk density. In: Methods of Soil Analysis, 2nd ed., part 1, Klute A. (Ed). Soil Sc. Soc.Amer.Madison, Wis.9: 363-375.

[8]. Chang, S.T. and Hayes, W.A. (2014): The biology and cultivation of gardenegg. Academic press, New York. 169-181

FUND/DESS/POLYUMUAGWO/RP/VOL VIII)

[9]. De-Song, E. (2010). The effect of a crude oil spill on cereals.Environ.Pollut. 22,:187-96. 
[10]. Fagbemi, T.N.F., Eleyinmi, A.F. Atum, H.N. and Akpanbang, O. (2005).Nutritional composition of fermented pumpkin seed for production of ogiriugu. Proceedings off the IFT annual meeting. P54B2, session 54B, fermented food and beverages: General

[11]. Henery, G. \& Hershey, C. (2002).Cassava in South America and Caribbean. In Hillocks, R. J., J. M. Thresh and A.C. Bellotti (Ed). Cassava: Biology, Production and Utilization. CABI Publishing Oxon, UK and New York, USA.pp: 17-40.

[12]. Kalichevsky, V.A. and Peters, E.H. (2010).Petroleum, our man of all work. The raw material, crude petroleum and natural gas. In Petroleum Products Handbook (V.B. Guthrie, ed.) pp. 1-22. New York: McGraw-Hill Book Company.

[13]. Kayode, J., Oyedeji, A.A., Olowoyo O (2009). "Evaluation of the effect of pollution with lubricant oil on the physical and chemical properties of soil". Pacific J. Sci. Tech. 10(1):387-391.

[14]. Nunes, D., Salgado, A.M., GamaRodrigues, E.F.D., TaketaniR.G., Cunha, C.D.D.and Servulo, E.F.C. Use of plant materials for the bioremediationof soil from an industrial site. J Environ sci health A ToxHazaedSubst Environ Eng55(6)650-660

[15]. Nwakaudu, et;al ( 2012) Impact of Cassava Processing Effluent on Agricultural Soil: A Case Study of Maize Growth.Journal of Emerging Trends in Engineering and Applied Sciences3(5): 881-885

[16]. Marschner, H. (2005). Mineral nutrition of higher plants.Second edition. Academic Press, New York, pp 889.

[17]. Obidike, D.I. (2015). Oil spill contingency planning Proc. Int. Seminar Pet. Ind. and the Nig. Environ., 11-14, pp. 145-56.

[18]. Ohanmu, E. O; Bako, S. P. and Adelanwa, MA (2017).Seasonal variation of Capsicum
frutescensL.(Chilli Pepper) to crude oil spill on soils from Ologbo, Edo State.Ann. Exp. Bio. 2 (3):31- 35 .

[19]. Ohanmu, E.O; Igiebor, F.A; Bako, S.P. andDanazumi,I.B. (2018).Impact of Crude Oil on Physicochemical Properties and Trace Metals of Soil before and after Planting of Two Pepper species (Capsicum annum L and C. frutescensL).J. Appl. Sci. Environ. Manage. 22 (5) $765-768$.

\section{Cite this article as :}

Nwodu J. A, Nwachukwu N, Ibegbulem C. O, Iwueke A. V, Akumefula M. I, Chukwuemeka U. V, Ohueri E. $\mathrm{O}$, " Health Implication of Physicochemical Properties of Sump Oil Polluted and Remediated Soil", International Journal of Scientific Research in Science and Technology(IJSRST), Print ISSN : 2395-6011, Online ISSN : 2395-602X, Volume 8, Issue 3, pp.854862, May-June-2021. Available at doi $\quad$ : https://doi.org/10.32628/IJSRST2183192 Journal URL : https://ijsrst.com/IJSRST2183192

\section{.}

